\title{
Strategus aloeus (COLEOPTERA: SCARABAEIDAE) DAMAGE AND ITS RELATIONSHIP WITH RAINFALL AND HYBRID OIL PALM AGE IN COLOMBIA
}

\section{LUIS GUILLERMO MONTES-BAZURTO ${ }^{1 *}$; ALEX ENRIQUE BUSTILLO-PARDEY1 and ANUAR MORALES RODRIGUEZ ${ }^{1}$}

\begin{abstract}
The adults of Strategus aloeus (L.) feed on the bulb and cause damage to young oil palm that can lead to lesions, and ultimately, to rotting. The aim of this study was to determine the S. aloeus damage in young hybrid oil palms, to propose an alternative method for its monitoring and control. Initially, destructive samplings of the palms were made at 8, 10, 12 and 15 days after insect attack. Additionally, weekly insect attack monitoring and rainfall register were made. About $44.4 \%$ of the oil palms were damaged after eight days of the adult's infestation. During the first year of the crop's establishment, there was a positive correlation between the number of galleries and rainfall. During the second and third year, there was a negative correlation between the number of galleries and oil palm age ( $\rho=-0.93 ; p<0.0001 ; n=105)$. Our study found that the damage caused by S. aloeus in hybrid cultivars can be observed eight days after the adult's arrival. The monitoring and control of S. aloeus in hybrid cultivars should be performed on a weekly basis from establishment to the first three and a half years of the crop.
\end{abstract}

Keywords: Elaeis oleifera x Elaeis guineensis, gallery, monitoring, rhinoceros beetle, rot.

Received: 26 May 2021; Accepted: 22 November 2021; Published online: 31 January 2022.

\section{INTRODUCTION}

The rhinoceros beetle Strategus aloeus (L.) (Coleoptera: Scarabaeidae) (Figure 1) is one of the most important pest in South America during the first few years of the establishment of oil palm crops (Ahumada et al., 1995; Aldana-De La Torre et al., 2017; Bedford, 1980; Chinchilla, 2003a). S. aloeus is a species with the largest geographic distribution within the genus Strategus, extending from the south of the United States to Brazil and Bolivia (Genty et al., 1978; Kim and Brou, 2018; Ratcliffe, 1976). In Colombia, it has been reported in replanting areas

1 Colombian Oil Palm Research Centre, Cenipalma, Palmar La Vizcaína Experimental Field, KM 132 Vía Puerto Araujo-La Lizama, Barrancabermeja, Santander, Colombia.

* Corresponding author e-mail: Igmontesb@unal.edu.co or in new crop establishments across all oil palm growing areas (Aldana-De La Torre et al., 2010; Calvache and Gomez, 1991). In addition to oil palm crops, it also infests coconut (Cocos nucifera L.) (Arecales: Arecaceae) plantations (Sanchez and Ortiz, 1997).

Strategus aloeus adult male causes damage by building a gallery that extends close to the palm bulb (Aldana-De La Torre et al., 2017; Bustillo-Pardey et al., 2016; Chinchilla, 2003b; Pallares et al., 2000) (Figure 2). Once the gallery is built, the male emits an aggregation pheromone, comprising a mixture of butanone, pentanone, and sec-butyl acetate (Rochat et al., 2000) that attracts the female. Both the female and male feed on the petiole bases, bulb, and stem of the oil palm, causing a lesion (Aldana-De La Torre et al., 2010; Aldana et al., 2000; Chinchilla, 2003a).

In oil palm [Elaeis guineensis Jacq. (Arecales: Arecaceae)], the damage can reach the meristem 


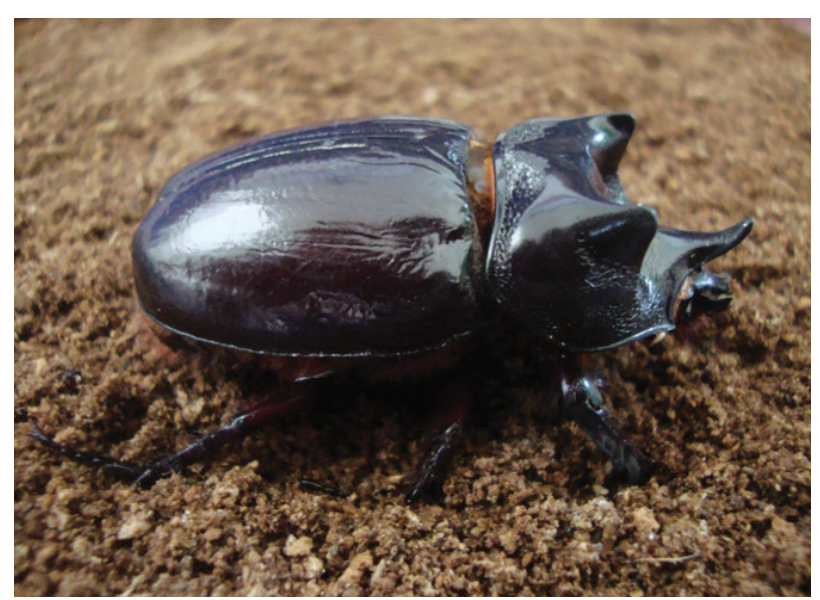

Figure 1. Adult male of Strategus aloeus.

eight days after the arrival of the male, leading to the death of the young palm (of less than one year old). If this does not occur, the lesion can be the entry point for microorganisms that cause stem or basal rots. One of the factors that influence the increase in gallery numbers in young palms is the start of the rainy season (Ahumada et al., 1995; Aldana-De La Torre et al., 2010). Similarly, the replanting system and the organic matter disposal in the field seem to influence the population abundance of $S$. aloeus. Replanting methods that produce stacking of palm into the plots tend to favour an increase in beetle populations (Ávila et al., 2014; Bustillo-Pardey et al., 2016) because the $S$. aloeus larvae are saprophagous (Aldana-De La Torre et al., 2010; Rivera-Gasperín and Escobar-Hernández, 2020).

The natural enemies of $S$. aloeus include the fungus Metarhizium anisopliae (Metchnikoff) Sorokin (Ascomycota: Hypocreales), which affects the larvae and adults and can be a promising alternative for pest control of this species (Bustillo-Pardey, 2014;
Bustillo-Pardey et al., 2016; Valencia et al., 2011), Nudivirus oryctes (Wang et al., 2007); previously called Baculovirus oryctes Huger virus that is pathogenic to S. aloeus adults (Lomer, 1987), and entomopathogenic nematodes that affect the larvae of S. aloeus (Gómez and Sáenz, 2015). In addition, Phileurus sp. (Coleoptera: Scarabaeidae) a predator of the larvae and pupae of $S$. aloeus can be found in the same organic matter in which $S$. aloeus reproduces (Aldana-De La Torre et al., 2010).

The management of $S$. aloeus in E. guineensis consists of eliminating the breeding sites (BustilloPardey et al., 2016; Ulloa et al., 2010), monitoring and controlling the galleries in young palms on a weekly basis. Insecticides are commonly sprayed in each gallery to control the adult $S$. aloeus, and the sprayed gallery is subsequently covered with soil (AldanaDe La Torre et al., 2010; Aldana et al., 2000; BustilloPardey et al., 2016).

Currently, Latin American countries are affected by bud rot disease and there have been an increase in oil palm replanting with $\mathrm{O} \times \mathrm{G}$ hybrid cultivars (E. oleifera $\times$ E. guineensis). Currently, there is a lack of knowledge regarding the damage caused by $S$. aloeus and its behaviour on these cultivars. Therefore, this study was designed to determine the damage caused by $S$. aloeus and to propose an alternative method for its monitoring and control in young hybrid cultivars.

\section{MATERIALS AND METHODS}

\section{Area of Study}

The study was conducted in plots of Coarí $x$ La Mé hybrid oil palm cultivar that were infested by S. aloeus, at the Palmas Monterrey plantation,

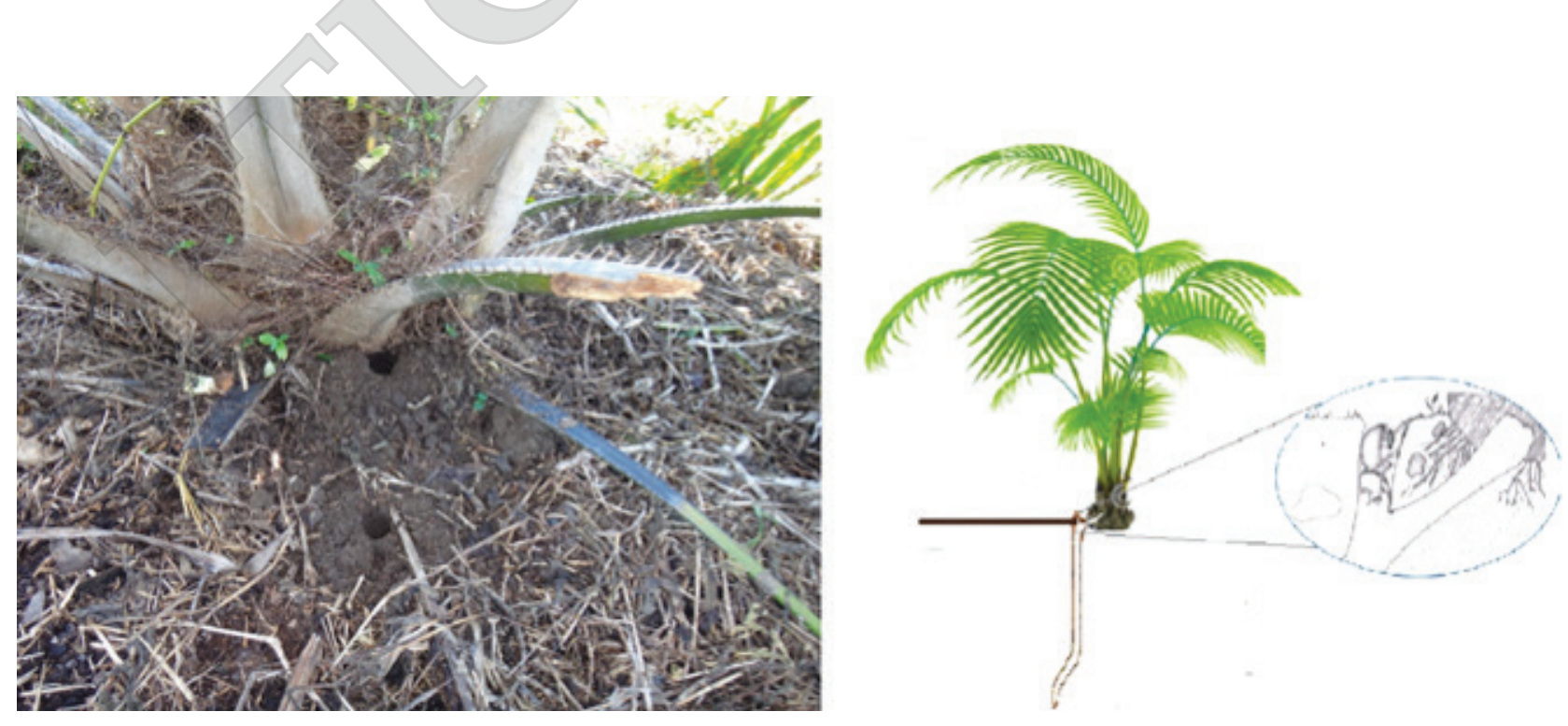

Figure 2. Galleries made by Strategus aloeus to palms during the first few years of crop establishment. Left image shows a real image of the galleries entrance beside of oil palm. Right image shows a graphical image of the gallery into the soil beside of oil palm. 
in Puerto Wilches, Santander, Colombia, (7 16' 14" North; 73०50' 21" West) with the following climatic characteristics: mean temperature of $29.5 \pm 5.9^{\circ} \mathrm{C}$, $86.3 \pm 19.8 \%$ relative humidity, $2152 \mathrm{~mm}$ of rainfall per year, and an elevation of $94 \mathrm{~m}$ above sea level.

\section{Description of the Damage Caused by S. aloeus}

Initially, 45 palms at 12 months of age were planted in an area that had a natural infestation of S. aloeus. The high infestation in the selected area of the plantation was due to the eradication method used when preparing the plot for replanting, which consisted of knocking down and stacking the eradicated palms. The eradication was performed three years prior to the start of this study.

After the establishment of the palms, daily monitoring was performed to document the arrival of adult S. aloeus. Once a gallery was found, the palm was marked and the evaluation of the treatments to the resulting damage was scheduled at $8,10,12$ and 15 days after the arrival of the adults to the palm. There were nine replicates for each treatment and the experimental unit was the palm naturally infested by $S$. aloeus.

The evaluation was destructive, as it was necessary to remove the palm from its site to examine the entire bulb. The damage was documented following examination of the bulb; determination whether the damage in the petiole base or in the bulb, and the diameter of the lesion was measured. The information was analysed by determining the proportion of damage in the young oil palms $(\%)$, the mean diameter of the lesion and its confidence intervals (CI) with $\alpha=0.05$.

\section{Strategus aloeus Infestation and Its Correlation with Rainfall and Palm Age}

Two commercial plots of the $\mathrm{O} \times \mathrm{G}$ hybrid palm cultivar, Coarí $\times$ La Mé, were selected to study the infestation by $S$. aloeus at different times from the establishment of the crop. In the first plot (P1), 250 palms (2.2 ha) were monitored weekly during the first year of cultivation from the establishment in the plantation, and the number of galleries per palm was recorded for one year. Once a gallery was found, it was sprayed with chlorpyrifos (Lorsban, Dow AgroSciences. Bogotá, Colombia) at the rate of $2.4 \mathrm{~g}$ of active ingredient/gallery, and the gallery was subsequently covered with soil. To spray the insecticide, the boom of a hand-operated 20-L backpack sprayer (Royal Condor, Bogota, Colombia) was introduced into $5 \mathrm{~cm}$ of the gallery.

Simultaneously, in the second plot (P2), the infestation by $S$. aloeus was monitored during the second and third year from the establishment of the palm in 432 palms ( 3.8 ha) that were planted 18 months prior to the start of this study. In this plot, weekly control treatments were conducted for two years, recording the number of $S$. aloeus galleries, spraying them with chlorpyrifos using the same spraying protocols used in P1 at the rate of $2.4 \mathrm{~g}$ of active ingredient/gallery, and then covering them with soil. Simultaneously, the weekly rainfall was recorded for each plot.

The analysis of the presence of $S$. aloeus galleries, age of the palm (in weeks), and rainfall in the two study plots was performed using Spearman's correlations. Data analysis was performed separately for the two study plots (P1 and P2) because of the experimental design and the availability of similar plots with different ages in the same conditions of replanting management. A second analysis was made together to analyse the complete time period of evaluation (three years and seven months).

\section{RESULTS AND DISCUSSION}

\section{Description of the Damage in Coarí $\times$ La Mé Hybrid Palms}

After eight days of the infestation of adult S. aloeus to the palms, $44.4 \%$ of the palms were injured at the petiole bases, while all palms were damaged after 15 days of the adult's arrival (Table 1). Damage to the meristem was not observed in any of the evaluated palms (Figure 3). There were no differences in the diameter of the lesion caused by the adult $S$. aloeus between the days after their arrival to the palms (Figure 4).

After reviewing the information on damage caused by $S$. aloeus in oil palms in previous studies compared to this study, it was found that the damage caused by the adult $S$. aloeus in hybrid oil palms (Coarí x La Me) and E. guineensis oil palms is similar in both cultivars. However, according to this study, the severity of the damage is lower in the hybrid palms as there were no death of palms occurred after 15 days of $S$. aloeus adults' infestation on the young palms. In E. guineensis palms, it has been reported that the damage to the meristem at

TABLE 1. PROPORTION OF DAMAGE IN YOUNG OIL PALMS CAUSED BY Strategus aloeus IN COARÍ $\times$ LA MÉ HYBRID OIL PALM CULTIVAR, RECORDED AFTER THE ARRIVAL OF THE ADULTS TO THE PALM IN FIELD CONDITIONS

\begin{tabular}{ccc}
\hline $\begin{array}{c}\text { Days after arrival } \\
\text { of the adult }\end{array}$ & $\mathbf{n}$ & $\begin{array}{c}\text { Proportion of palms } \\
\text { with damage (\%) }\end{array}$ \\
\hline 8 & 9 & 44.4 \\
10 & 9 & 55.6 \\
12 & 9 & 77.8 \\
15 & 9 & 100.0 \\
\hline
\end{tabular}



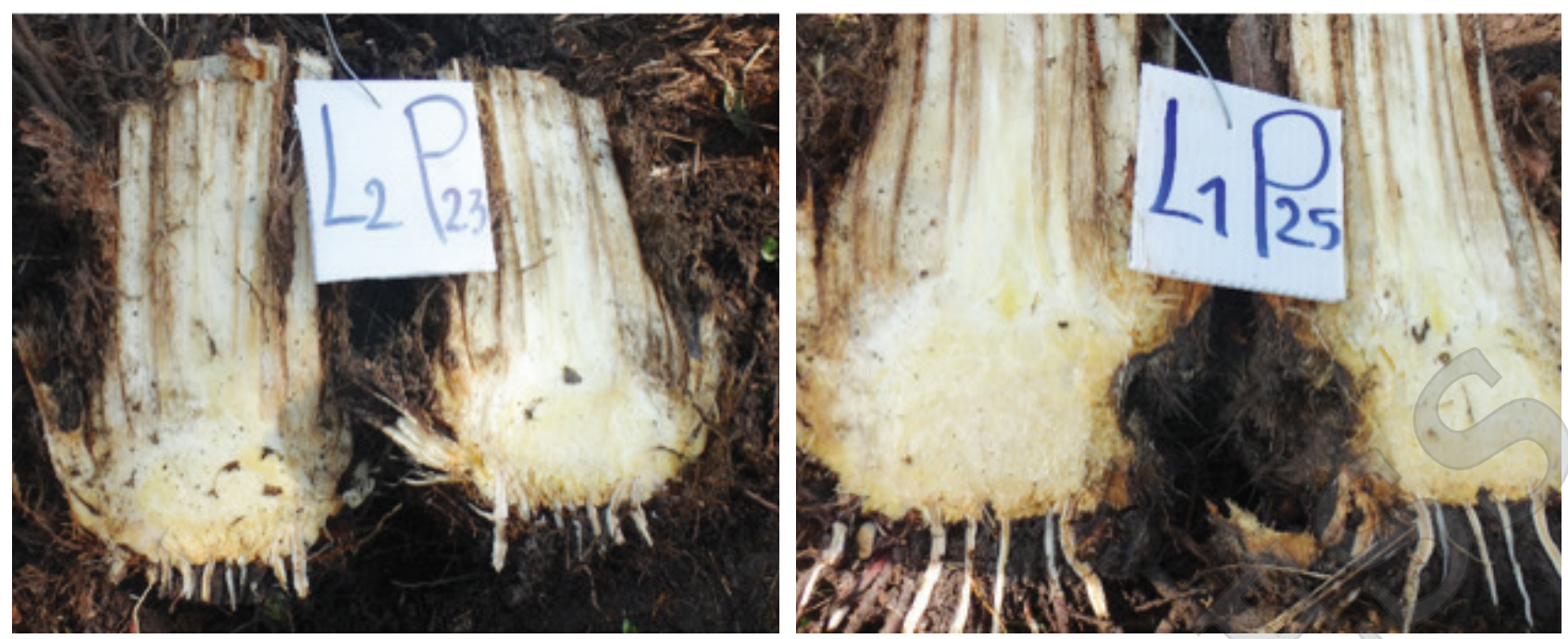

Figure 3. Bulbs of 12-month-old Coarí $\times$ La Mé hybrid palm planted in a plot infested with Strategus aloeus. Left image shows a bulb with a vertical cut without damage. Right image shows bulb with a vertical cut with damage without affecting the meristem.

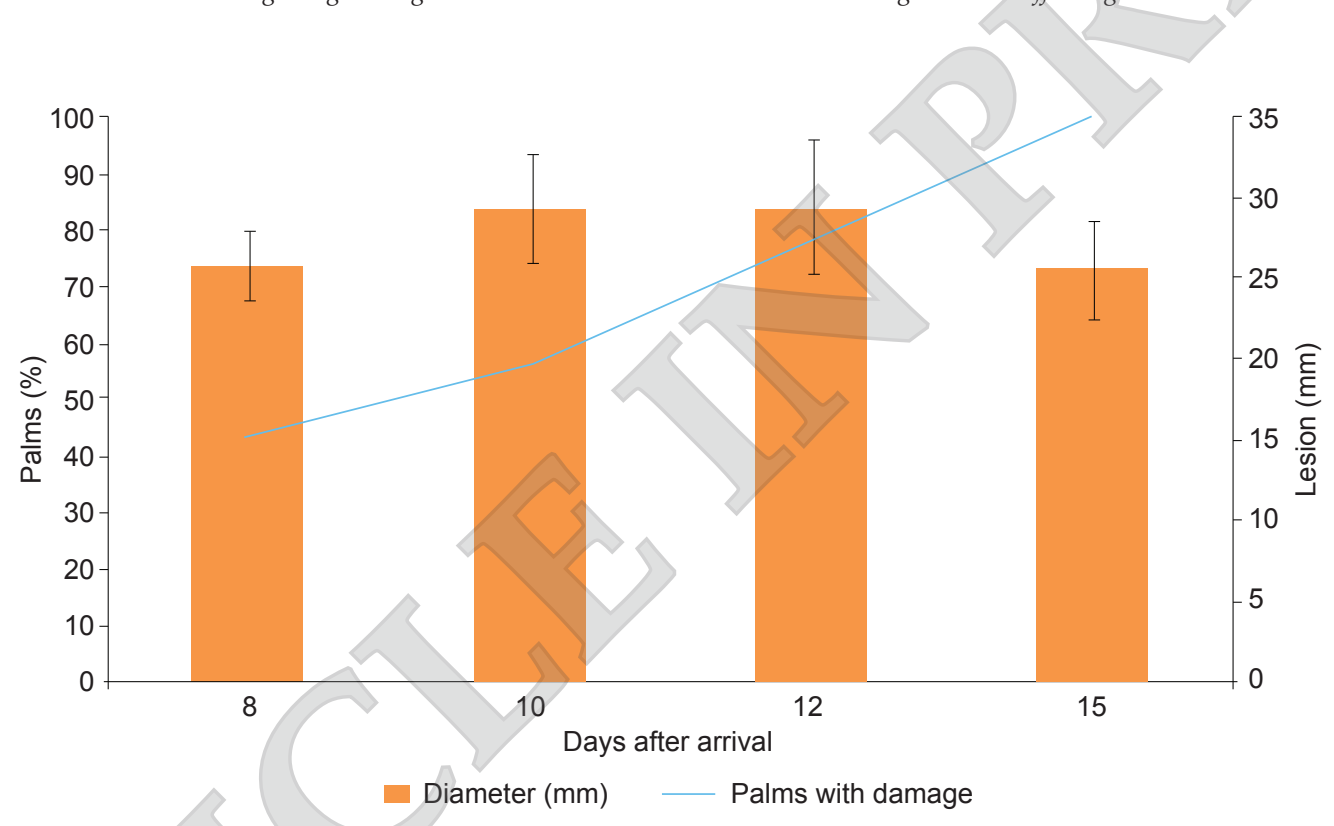

Figure 4. Mean diameter of the lesion and its standard deviation (SD) caused by Strategus aloeus in the petiole base of the Coarí $\times$ La Mé hybrid oil palm cultivar and the young oil palm proportion with damage; recorded between 8 and 15 days after the arrival of the adults to the palm at field conditions.

eight days after the arrival of the adult can lead to the death of the young palm (Aldana-De La Torre et al., 2010; Genty et al., 1978).

Furthermore, the lesions caused by S. aloeus in palms under the age of three years can be the entry point for pathogens that cause palm stem rots (Ahumada et al., 1995; Aldana et al., 2000; BustilloPardey et al., 2016). Therefore, it is necessary to control the galleries on a weekly basis in E. guineensis and hybrid cultivars (Morales Ipuz et al., 2017). The difference in damage between both cultivars can be associated with the robustness of the tissues of the hybrid cultivars, by having less damage severity. However, it is necessary to conduct further studies to corroborate or rule out this hypothesis.

\section{Strategus aloeus Infestation and its Correlation with Rainfall and Palm Age}

The first gallery built by S. aloeus was observed 22 days after the establishment of the palm in the P1. During the first year of establishment, there was a positive correlation between the number of galleries and rainfall $(\rho=0.44 ; \mathrm{p}=0.0042 ; \mathrm{n}=40)$ (Figure 5). There was no correlation between the number of galleries and the age of the hybrid cultivar palm during the first year of the establishment of the $\operatorname{crop}(\rho=0.18 ; \mathrm{p}=0.2640 ; \mathrm{n}=40)$.

Based on the weekly controls conducted in the P2, there was no correlation between the number of galleries made by $S$. aloeus and the weekly rainfall $(\rho=0.05 ; \mathrm{p}=0.5956 ; \mathrm{n}=105)$. However, there 


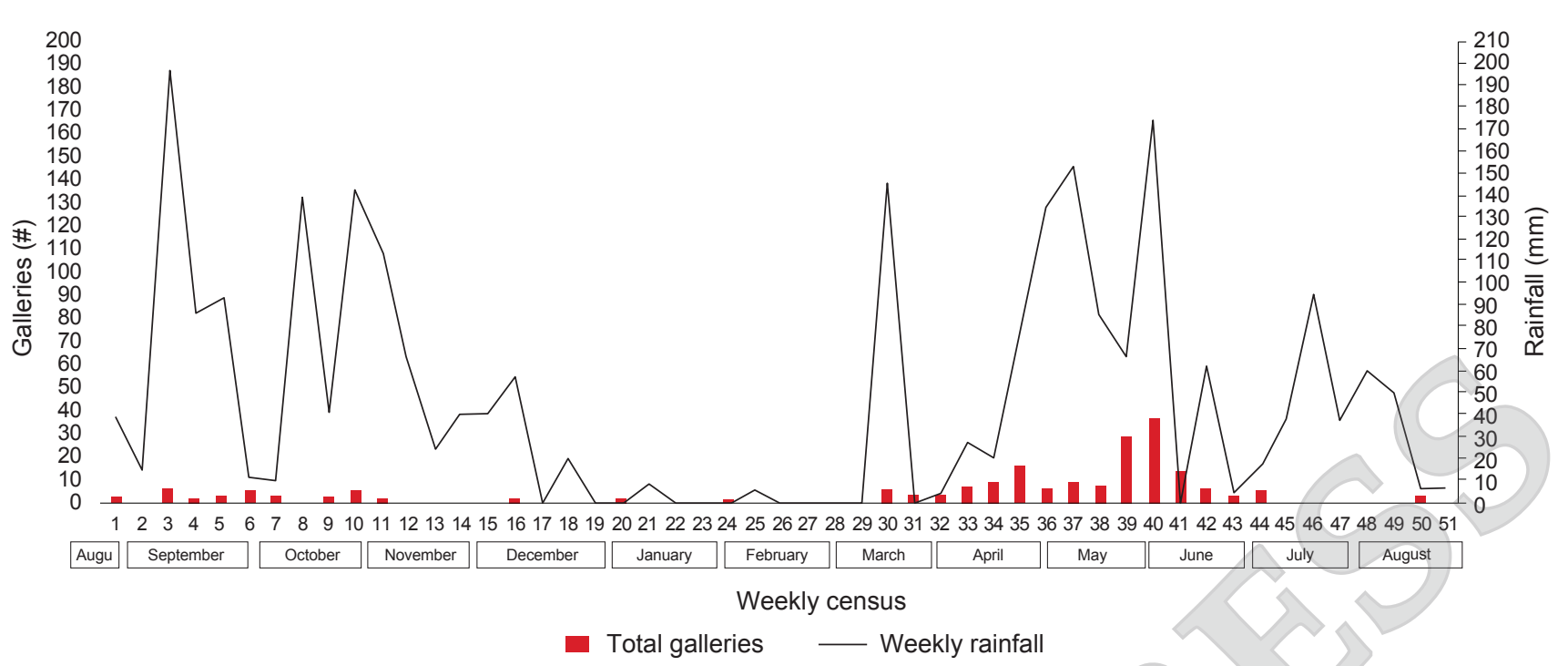

Figure 5. Total number of galleries of Strategus aloeus and rainfall, recorded weekly in plot 1 (P1) of Coari × La Mé hybrid oil palm cultivar, which was planted at the start of the study.

was a negative correlation between the number of galleries and palm age $(\rho=-0.93 ; \mathrm{p}<0.0001 ; \mathrm{n}=105)$. The last gallery was recorded 183 weeks (3 years 6 months) after the establishment of the crop (Figure 6).

In the analysis of all evaluation period from the establishment to the first 3 years 7 months of the crop in both plots, there was no correlation found between the number of galleries and the rainfall $(\rho=0.12 ; p=0.1453 ; \mathrm{n}=156)$; and there was a negative correlation between the number of galleries and palm age $(\rho=-0.16 ; p=0.0422 ; n=156)$. However, there was a difference in the abundance of the S. aloeus adult population in both plots. At 51 weeks after establishment, there were no galleries found in P1 compared to 85 galleries found in P2 at 52 weeks after establishment. These two plots had the same cultivar and similar replanting management conditions. The only difference between them was the age and its S. aloeus natural infestation.

In the Coarí $\times$ La Mé hybrid cultivar, as in nonhybrid cultivars, S. aloeus infestations were reported in young palms during the first few years of cultivation (Aldana-De La Torre et al., 2017; BustilloPardey et al., 2016). Therefore, the monitoring and control of this insect should be conducted starting from when the crop was established, up to three and a half years of the crop.

The positive correlation between the number of galleries constructed by adult $S$. aloeus and the rainfall recorded during the first few years of the establishment of the Coarí $\times$ La Mé hybrid oil palm (Figure 5) was consistent with that reported in E. guineensis oil palms, where an increase in

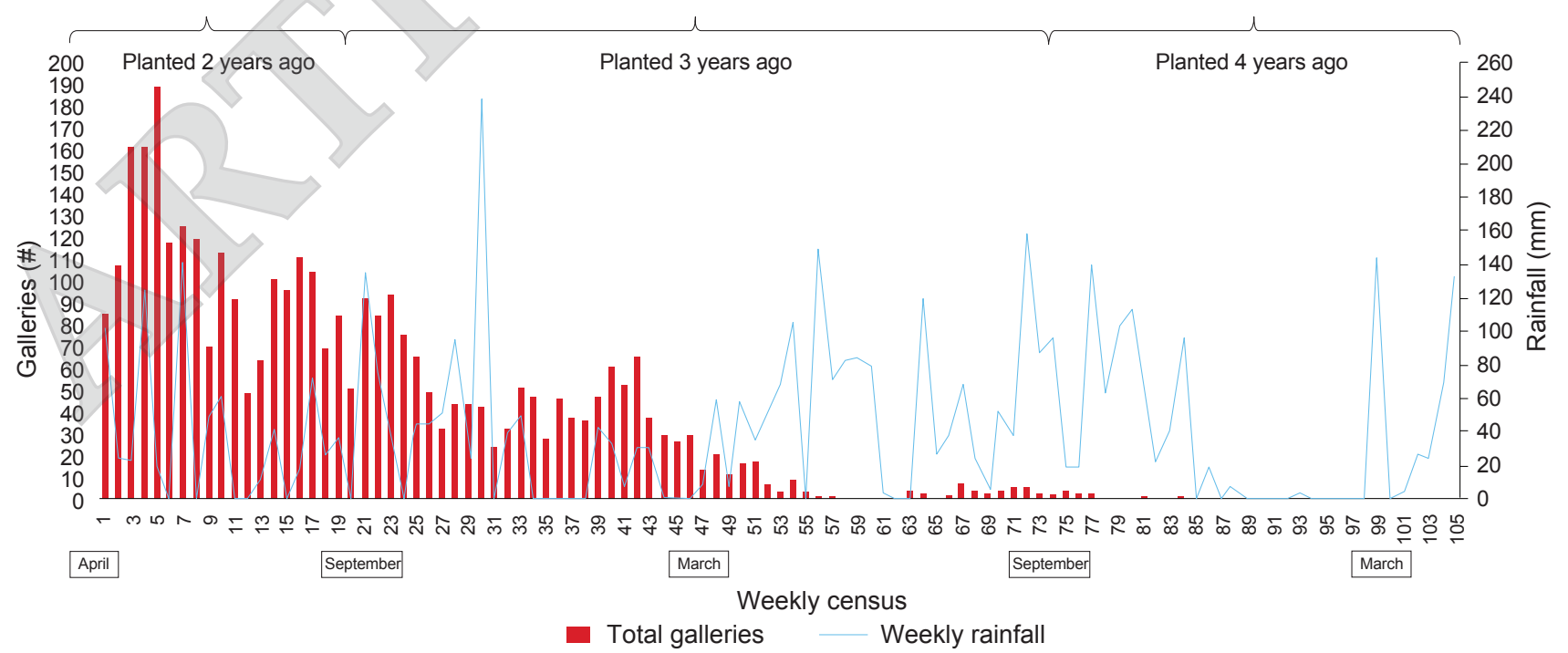

Figure 6. Total number of galleries of Strategus aloeus and rainfall recorded weekly in plot 2 (P2) of Coarí × La Mé hybrid oil palm cultivar, which was 18 months old at the start of the study. 
the number of galleries after the start of the rainy season was observed (Ahumada et al., 1995; Genty et al., 1978). Furthermore, the results of this study are in agreement with other studies that show a positive correlation between Diastocera trifasciata (Fabricius) (Coleoptera: Cerambycidae) populations and rainfalls registered in cashew orchards (Akessé et al., 2018) or between Cosmopolites sordidus Germar (Coleoptera: Curculionidae) and the rainfall registered in banana plantation in Africa (Uzakah and Olorunfemi, 2019).

However, after 18 months of the establishment of the crop, there was no association in the Coarí $\times$ La Mé hybrid cultivar between the number of galleries made by S. aloeus and rainfall (Figure 6), owing to the presence of overlapping generations of the insect where the females are permanently ovipositing in the waste. In other pest like Oryctes owariensis Beavois, 1807 (Coleoptera: Scarabaeidae: Dynastinae) or wood-boring Coleoptera [Bostrichidae and Curculionidae (Scolytinae and Platypodinae)], the population seem to increase during the dry season (less rainfalls) (Sanguansub et al., 2020; Ukaroije and Abalis, 2020). In the same way, the rainfall can also cause larval mortality as in Anthonomus pomorum L. (Coleoptera: Curculionidae) (Popov and Dmitrieva, 2020), but according to this study, after 18 months of the hybrid palm crop establishment, the abundance of $S$. aloeus adults did not seem to be affected by the rainfall variation. The age of the palms (between 18 and 30 months) and high levels of S. aloeus populations seem to be the most important factors associated with damage in plots of the Coarí $x$ La Mé hybrid oil palm cultivar.

\section{CONCLUSION}

The damage caused by S. aloeus in Coarí $\times$ La Mé hybrid cultivars was observed at eight days after the arrival of the adult males to the palm. The damage caused by S. aloeus in Coarí $\times$ La Mé hybrid cultivars was not lethal to the palm as it does not affect the meristem, even after 15 days of arrival of the adults to the palm. The monitoring and control of S. aloeus in Coarí $\times$ La Mé hybrid cultivars should be performed on a weekly basis since the establishment of the crop up to the first three and a half years of the crop, in order to avoid the pest from causing damage to the palm.

\section{ACKNOWLEDGEMENT}

The authors would like to thank Nestor Pulido, Agronomic Director and Enerilson Torrecillas (RIP), Chief of Plant Health of the Palmas Monterrey plantation for their support in developing this study. They also thank the Oil Palm Development
Fund and the Ministry of Agriculture and Rural Development of Colombia for financing of this study.

\section{REFERENCES}

Ahumada, F M L; Calvache, G H H; Cruz, C M A and Luque, Z J E (1995). Strategus aloeus (L.) (Coleoptera: Scarabaeidae): Biología y comportamiento en Puerto Wilches (Santander). Palmas (Colombia), 16(3): 9-16.

Akessé, E; Ouali-N'Goran, S-W; N’Dépo, O R and Tano, D K C (2018). Population fluctuation of Diastocera trifasciata (Fabricius, 1775) (Coleoptera: Cerambycidae), cashew branches girdler in the Brobo locality (Central Côte d' Ivoire). J. Entomol. Zool. Stud., 6(5): 1064-1070.

Aldana-De La Torre, R C; Aldana, J; Calvache, $\mathrm{H}$ and Franco, P (2010). Manual de plagas de la palma de aceite en Colombia Bogota, Cenipalma.

Aldana-De La Torre, R C; Montes-Bazurto, L G; Barrios, C; Matabanchoy, J; Beltran, I J; Rosero, M and Bustillo-Pardey, A E (2017). Guía de bolsillo para el reconocimiento de las plagas más frecuentes en la palma de aceite Bogota, Cenipalma.

Aldana, J; Pallares, C and Correa, N (2000). Control quimico de Strategus aloeus (L.) (Coleoptera: Scarabaeidae). Ceniavances (Colombia), 67: 1-4.

Ávila, R A; Bayona, C; Rincón, Á and Romero, H M (2014). Effect of replanting systems on populations of Strategus aloeus (L.) and Rhynchophorus palmarum (L.) associated with the oil palm $\mathrm{O} \times \mathrm{G}$ interespecific hybrid (Elaeis oleifera $\times$ Elaeis guineensis) in Southwestern Colombia. Agron. Colomb., 32(2): 224-231.

Bedford, G O (1980). Biology, ecology and control of palm Rhinoceros beetles. Annu. Rev. Entomol., 25: 309-339.

Bustillo-Pardey, A E (2014). Manejo de insectos-plaga de la palma de aceite con énfasis en el control biológico y su relación con el cambio climático. Revista Palmas (Colombia), 35(4): 66-77.

Bustillo-Pardey, A E; Sarria, G; Aldana-De La Torre, R C and Arango, M (2016). Guia de bolsillo para el reconocimiento y manejo de las principales enfermedades e insectos plaga en el cultivo de la palma de aceite Bogota, Fedepalma.

Calvache, H and Gomez, P L (1991). Comportamiento de las plagas de la palma de aceite en Colombia durante 1990. Revista Palmas (Colombia), 12(3): 7-14. 
Chinchilla, C (2003a). Manejo Integrado de problemas fitosanitarios en palma aceitera Elaeis guineensis en América Central. Manejo Integr. Plagas y Agroecol., 67: 69-82.

Chinchilla, C (2003b). Manejo integrado de problemas fitosanitarios en palma de aceite Elaeis guineensis en America Central. Manejo Integr. Plagas y Agroecol., 67: 69-82.

Genty, P; Desmier de Chenon, R and Morin, J P (1978). Oil palm pest in Latin America. Oleagineux, 33(7): 334-335.

Gómez, A and Sáenz, A (2015). Susceptibility variation to different entomopathogenic nematodes in Strategus aloeus L. (Coleoptera: Scarabaeidae). Springerplus, 4(620): 1-5.

Kim, J and Brou, V (2018). The genus Strategus Kirby (Coleoptera: Scarabaeidae: Dynastinae) in Louisiana. South. Lepid. News, 40(2): 100-105.

Lomer, C J (1987). Infection of Strategus aloeus (L.) (Coleoptera: Scarabaeidae) and other Dynastinae with Baculovirus oryctes. Bull. Entomol. Res., 77(1): 45-51.

Morales Ipuz, L C; Neira Segura, Á L and BecerraEncinales, J F (2017). Aplicación de mejores prácticas fitosanitarias en el cultivo de la palma de aceite Bogota, Cenipalma.

Pallares, C; Aldana, J; Calvache, H; Ramírez, P; Rochat, D; Luque, E and Correa, N (2000). Análisis del comportamiento y comunicación química intraespecífica en Strategus aloeus (L.) (Coleóptera, Scarabaeidae Dynastinae). Revista Palmas (Colombia), 21(especial tomoI): 185-194.

Popov, S Y and Dmitrieva, S V (2020). Life tables of the apple blossom weevil populations (Anthonomus pomorum L.) (Coleoptera, Curculionidae) on apple and pear trees in urbanized territories of Moscow and Tver provinces. Entomol. Rev., 100(5): 577-586.

Ratcliffe, BC (1976). A revision of the Genus Strategus (Coleoptera: Scarabaeidae). Bull. Univ. Nebraska State Museum, 10(3): 93-204.

Rivera-Gasperín, S and Escobar-Hernández, F (2020). Especies de Scarabaeoidae (Coleoptera) del Cicolma, Veracruz, Mexico. Acta Zoológica Mex., 36: 1-19.
Rochat, D; Ramirez-Lucas, P; Malosse, C; Aldana-De La Torre, R C; Kakul, T and Morin, J P (2000). Role of solid-phase microextraction in the identification of highly volatile pheromones of two Rhinoceros beetles Scapanes australis and Strategus aloeus (Coleoptera, Scarabaeidae, Dynastinae). J. Chromatogr. A, 885(1-2): 433-444.

Sanchez, S and Ortiz, C (1997). Presencia de Strategus aloeus L. (Scarabaeidae) en el estado de Tabasco, México Strategus aloeus L. (Scarabaeidae) en el estado de Tabasco, México. ASD Oil Palm Pap. (Costa Rica), 16: 31-34.

Sanguansub, S; Buranapanichpan, S; Beaver, R A; Saowaphak, T; Tanaka, N and Kamata, N (2020). Influence of seasonality and climate on captures of wood-boring Coleoptera [Bostrichidae and Curculionidae (Scolytinae and Platypodinae)] using ethanol-baited traps in a seasonal tropical forest of Northern Thailand. J. For. Res., 25(4): 223231.

Ukaroije, R B and Abalis, R O (2020). Population dynamics and seasonal abundance of the beetle Oryctes owariensis beavois, UK 1807 (Coleoptera: Scarabaeidae: Dynastinae) in Raphia palms in Bayelsa State, Nigeria. Asian J. Biol., 9(3): 14-27.

Ulloa, A; Moya-Murillo, O M; Rincón, Á; AldanaDe La Torre, R C; Gomes de Oliveira, H; Ruiz, R and Ávila, R A (2010). Dinámica de reproducción de Strategus aloeus bajo diferentes métodos de erradicación y daño causado en la nueva siembra. Ceniavance, 166: 1-4.

Uzakah, R P and Olorunfemi, D I (2019). Population dynamics of the plantain-banana weevil Cosmopolites sordidus Germar (Coleoptera: Curculionidae) in Bayelsa State, Southern Nigeria. African Sci., 20(4): 193-199.

Valencia, C; Pérez, S; Aldana-De La Torre, R C; Mesa, E and Gomes de Oliveira, H (2011). Patogenicidad de hongos entomopatógenos del género Metarhizium sobre larvas de Strategus aloeus L. (Coleoptera: Scarabaeidae), en condiciones de laboratorio. Revista Palmas (Colombia), 32(4): 30-40.

Wang, Y; Van Oers, M M; Crawford, A M; Vlak, J M and Jehle, J A (2007). Genomic analysis of Oryctes rhinoceros virus reveals genetic relatedness to Heliothis zea virus 1. Arch. Virol., 152(3): 519-531. 